Tropical Journal of Pharmaceutical Research August 2020; 19 (8): 1677-1684

ISSN: $1596-5996$ (print); 1596-9827 (electronic) (C) Pharmacotherapy Group, Faculty of Pharmacy, University of Benin, Benin City, 300001 Nigeria.

\title{
Computational and pharmacological evaluation of stevioside derivatives for antinociceptive and anti- inflammatory potential
}

\author{
Sadaf Ahmad1, Arif-ullah Khan ${ }^{1}$, Muhammad Faheem ${ }^{1 *}$, Muhammad Shahid \\ Iqbal $^{2}$, Mohammad Akbar Hossain ${ }^{3}$, Asad Ullah ${ }^{4}$, Shabir Ahmad ${ }^{4}$ \\ ${ }^{1}$ Riphah Institute of Pharmaceutical Sciences, Riphah International University, Islamabad, Pakistan, ${ }^{2}$ Department of Clinical \\ Pharmacy, College of Pharmacy, Prince Sattam Bin Abdulaziz University Alkharj, Saudi Arabia, ${ }^{3}$ Department of Pharmacology \\ and Toxicology, College of Pharmacy, Umm Al-Qura University, Makkah al Mukarramah, Saudi Arabia, ${ }^{4}$ Department of \\ Pharmacology and Toxicology, College of Medicine, Umm Al-Qura University, Makkah, Saudi Arabia
}

*For correspondence: Email: muhammad.faheem@riphah.edu.pk, Tel: +92-3009021523

Sent for review: 22 October 2019

Revised accepted: 19 July 2020

\begin{abstract}
Purpose: To carry out computational and pharmacological evaluation of two stevioside derivatives in order to develop more effective candidates for analgesia and inflammation.

Methods: Primarily, compounds were docked against targets of nociception and inflammation such as cyclooxygenase-1, cyclooxygenase-2, 5-lypooxygenase 12-lypooxygenase, 15-lypooxygenase, prostaglandin synthase, leukotrienes $\mathrm{C} 4$ synthase, mu, kappa, and delta receptors to obtain their possible binding modes. Test compounds were then screened in animal model of nociception and inflammation.

Results: The results of docking show that 10 possesses good affinity when compared to ID. IO showed two hydrogen bonds against COX-1 and COX-2. 10 also demonstrated good binding against 5-LOX, 12LOX and 15-LOX, exhibited four, one and two hydrogen bonds respectively. Against PG synthase and LTC4, both $1 O$ and ID produced moderate binding. 10 also showed significant binding against opoid receptors $(p<0.05)$. $I O$ and ID significantly decrease the number of writhes to $21.20 \pm 2.1$ and $27.0 \pm$ 2.12 at $10 \mathrm{mg} / \mathrm{kg}$ in acetic acid mediated pain test respectively. In hot plate method, IO and ID increase the latency period of mice to $14.14 \pm 0.40$ and $10.50 \pm 0.34 \mathrm{~s}$, respectively. $I O$ and ID significantly reduced the paw edema to $1.69 \pm 0.14$ and $1.94 \pm 0.14 \mathrm{~mL}$, respectively, in acute inflammation $(p<$ 0.05). In chronic inflammatory model, $I O$ and ID decreased paw volume to $3.26 \pm 0.38$ and $4.20 \pm 0.38$ $m L$, respectively.

Conclusion: The results show that 10 is a promising candidate for further development as analgesic and anti-inflammatory agents. However, their pharmacokinetic and pharmacodynamic profiles need to be investigated.
\end{abstract}

Keywords: Computational, Stevioside, Docking, Analgesic, Anti-inflammatory

This is an Open Access article that uses a fund-ing model which does not charge readers or their institutions for access and distributed under the terms of the Creative Commons Attribution License (http://creativecommons.org/licenses/by/4.0) and the Budapest Open Access Initiative (http://www.budapestopenaccessinitiative.org/read), which permit unrestricted use, distribution, and reproduction in any medium, provided the original work is properly credited.

Tropical Journal of Pharmaceutical Research is indexed by Science Citation Index (SciSearch), Scopus, International Pharmaceutical Abstract, Chemical Abstracts, Embase, Index Copernicus, EBSCO, African Index Medicus, JournalSeek, Journal Citation Reports/Science Edition, Directory of Open Access Journals (DOAJ), African Journal Online, Bioline International, Open-J-Gate and Pharmacy Abstracts 


\section{INTRODUCTION}

Stevioside was first isolated from leaves of Stevia rebaudiana Bertoni, a perennial herb belongs to family asteraecea [1]. It is composed of steviol, a dieterpene carboxylic alcohol and three molecules of glucose and is used as a sweetener. Steviol is the metabolite, obtained by enzymatic hydrolysis of Stevioside [2]. Pharmacologically, stevioside are effective in controlling obesity, atherosclerosis [3], hypertension, diabetes mellitus [4], cancer, inflammation [5], and free radical scavenging activities [6]. Based on their wide spectrum in both medicine and food, two derivatives of steviol glycosides, namely isosteviol 16-Oxime (IO) and isosteviol 16-2, 4 dinitrophenyl hydrazine (ID) were utilized in this research. The synthesis, antitrypanosomal and antimalarial potential of these compounds have already been published [7]. The structures of 10 and ID are shown in Figure 1. Both compounds were screened to check their binding affinity against various targets of pain and inflammation. After in-silico screening, IO and ID were also evaluated for in-vivo experimentation in determining their analgesic and antiinflammatory potential in different animal models as acetic acid induced pain, thermal nociception, carrageenan and formalin mediated paw inflammation. The first two models were utilized for evaluating pain perception and thermal latency. The latter two models were used for determining the acute and chronic antiinflammatory potential of mentioned derivatives.

(IO)<smiles>CC12CCC3C1CCC3(C)CC(=NO)C2</smiles>

(ID)<smiles>CC12CCC3C(CCC4C3(C)CCC[C@]4(C)C(=O)O)(C/C1=N\Nc1ccc([N+](=O)[O-])cc1[N+](=O)[O-])C2</smiles>

Figure 1: Structure of compounds: Isosteviol 16Oxime (IO) and Isosteviol 16-2, 4 dinitrophenyl hydrazine (ID)

\section{EXPERIMENTAL}

\section{Materials}

Acetic acid, carrageenan, diclofenac sodium, dimethylsulfoxide (DMSO), formalin, tramadol. (Sigma Chemicals. Dt. Louis, MO, USA). IO and ID were used in 5 and $10 \mathrm{mg} / \mathrm{kg}$ in all experimental model. Diclofenac sodium and toradol were used in 20 and $30 \mathrm{mg} / \mathrm{kg}$ respectively.

\section{Animals}

Swiss albino mice $(25-30 \mathrm{~g})$ and Sprague Dawley rats $(200-250 \mathrm{~g})$ were utilized. The animals were kept under control environment $(23$ $-25^{\circ} \mathrm{C}$ ) without restriction to water and food. The approval of research was granted by Research and Ethical Committee of Riphah Institute of Pharmaceutical Sciences (ref no. REC/RIPS/2016/007). The research was carried as per guidelines of Institute of Laboratory Animal Resources, Commission on Life Sciences University, National Research Council, 1996 [8].

\section{Computational evaluation}

The three-dimensional target proteins were obtained from (http://www.rcsb.org/pdb/) in PDB format with their respective protein data bank entries shown in Table 1. The water molecules and attached ligand were removed through Biovia Discovery Studio Visualizer Client (DSVC) 2016. The 3D structures of ligands were drawn and saved in PDB format through DSVC 2016. The targets and ligands were further converted to PBDqt format through Auto dock vina and saved for further processing. The 3D structure of the standard drugs including diclofenac sodium (PubChem CID: 5018304) and zilueton (PubChem CID: 60490) and morphine (PubChem CID: 249332) for the purpose of analgesic (Central and peripheral analgesic activity) and anti-inflammatory activities were obtained from pubchem (https://pubchem.ncbi.nlm.nih.gov/search/).

\section{Assessment of acetic acid induced writhing in mice}

The analgesic effect of $\mathrm{IO}$ and ID was determined by using acetic acid induced writhing method in mice [10]. Before $0.7 \%$ injection of acetic acid, the mice were injected with saline, test compound and diclofenac sodium and writhes were counted for $20 \mathrm{~min}$. 
Table 1: Targets (COX 1, COX 2, 5 LOX, 12 LOX, 15 LOX, PG Synthase, LTC4 Synthase, Mu, Kappa, Delta) and their PDB IDs, score/E-value (Kcal/mol), no of hydrogen bonds, amino acid residues of isosteviol 16-Oxime (IO), isosteviol 16-2, 4 dinitrophenyl hydrazine (ID) diclofenac sodium, zileuton and morphine interpreted through Biovia Discovery Studio Visualizer client 2016

\begin{tabular}{|c|c|c|c|c|c|c|c|c|c|c|c|}
\hline \multirow[b]{2}{*}{ Target } & \multirow[b]{2}{*}{$\begin{array}{l}\text { PDB } \\
\text { IDs }\end{array}$} & \multicolumn{3}{|r|}{10} & \multicolumn{3}{|c|}{ ID } & \multicolumn{4}{|c|}{ Standard drugs } \\
\hline & & Score & $\begin{array}{c}\text { No of } \\
\text { H-Bond }\end{array}$ & Bonding residues & Score & $\begin{array}{c}\text { No of } \\
\text { H-Bond }\end{array}$ & $\begin{array}{l}\text { Bonding } \\
\text { residues }\end{array}$ & Standard & Score & $\begin{array}{c}\text { No of } \\
\text { H-bond }\end{array}$ & $\begin{array}{l}\text { Bonding } \\
\text { residues }\end{array}$ \\
\hline $\operatorname{cox} 1$ & $3 \mathrm{KK} 6$ & -9.8 & 02 & $\begin{array}{l}\text { SER } 127 \\
\text { ILE } 125\end{array}$ & -9.1 & 00 & - & $\begin{array}{l}\text { Diclofenac } \\
\text { sodium }\end{array}$ & -7.9 & 01 & GLY 25 \\
\hline $\operatorname{cox} 2$ & $5 \mathrm{IKQ}$ & -10 & 02 & $\begin{array}{l}\text { PHE } 471 \\
\text { GLU } 525\end{array}$ & -8.9 & 01 & TYR 131 & $\begin{array}{l}\text { Diclofenac } \\
\text { sodium }\end{array}$ & -7.8 & & $\begin{array}{l}\text { GLY } 25 \\
\text { HIS } 26 \\
\text { VAL } 28\end{array}$ \\
\hline 5 LOX & $1 Y P Q$ & -7.4 & 04 & $\begin{array}{l}\text { ARG } 138,165 \\
\text { ASP } 166 \text { TYR } 142\end{array}$ & -6.5 & 02 & $\begin{array}{c}\text { TYR 100, } \\
142\end{array}$ & Zileuton & -7.2 & 01 & TYR 81 \\
\hline 12 LOX & 3D3L & -9.1 & 01 & ASP 646 & -6.3 & 00 & - & Zileuton & -7.4 & 02 & $\begin{array}{l}\text { LEU } 597 \\
\text { CYS } 656\end{array}$ \\
\hline 15 LOX & 4NRE & -8.7 & 01 & TYR 107 & -6.4 & 01 & ARG 407 & Zileuton & 7.0 & 02 & $\begin{array}{l}\text { GLN } 108 \\
\text { TYR } 149\end{array}$ \\
\hline PG Synthase & 3DWW & -8.8 & 01 & TYR 55 & -6.2 & 01 & SER 217 & Zileuton & -6.3 & 03 & $\begin{array}{c}\text { ARG } 66 \\
\text { ASN } 198 \\
\text { SER } 200\end{array}$ \\
\hline $\begin{array}{l}\text { LTC4 } \\
\text { Synthase }\end{array}$ & 3PNO & -7.0 & 01 & GLY 124 & -6.6 & 02 & $\begin{array}{l}\text { ILE } 168 \\
\text { SER } 96\end{array}$ & Zileuton & -5.2 & 01 & SER 122 \\
\hline $\mathrm{Mu}$ & 4DKL & -7.8 & 02 & $\begin{array}{l}\text { HIS } 967 \\
\text { TYR } 962\end{array}$ & -6.8 & 00 & - & Morphine & -8.9 & & $\begin{array}{c}\text { ASN } 990 \\
\text { ASP } 1015 \\
\text { LEU } 1026\end{array}$ \\
\hline Kappa & 4DJH & -8.2 & 01 & TYR 386 & -7.4 & 00 & & Morphine & -9.3 & 01 & GLY 2 \\
\hline Delta & 4EJ4 & -7.5 & 01 & THR 260 & -6.6 & 01 & SER 143 & Morphine & -9.4 & 01 & TYR 308 \\
\hline
\end{tabular}

Aspartic acid $=$ ASP, Cysteine $=$ CYS, Glutamine $=$ GLN, Glutamic acid $=$ GLU, Glycine $=$ GLY, Histadine $=$ HIS, Asparagine $=$ ASN Arginine $=$
LYS , Leucine $=$ LEU, Methionine $=$ MET, Phenylalanine $=$ PHE Serine $=$ SER Tryptophan $=$ TRP, Threonine $=$ THR, Tyrosine $=$ TYR Valine 


\section{Hot plate test}

The pain killing effect of $I O$ and ID was determined using hot plate method in mice [11]. The mice were pretreated with saline, test compound and tramadol before placing on hot plate. Paw licking/ jumping from the plate, noted as latency period at 30,60, 90 and $120 \mathrm{~min}$. The cutoff time was $20 \mathrm{sec}$ to avoid paw injury of mice.

\section{Determination of carrageenan-induced paw edema}

The anti-inflammatory effect of $\mathrm{IO}$ and ID was determined using carrageenan mediated acute inflammation in rats [12]. After $30 \mathrm{~min}$ of treatment, $0.1 \mathrm{~mL}$ carrageenan $(1 \%)$ was injected in sub-aponeurotic region of hind paw and changes in the paw volume were recorded at $1,2,3$ and $4 \mathrm{~h}$ by using plethysmometer (model: UGO Basile S.R.L, 7141).

\section{Evaluation of formalin-induced paw edema}

The effect against chronic inflammation was determined by using formalin mediated chronic inflammation rats [13]. After $30 \mathrm{~min}$ of treatment with saline, test compound and diclofenac sodium chronic inflammation was induced by sub-aponeurotic injection of formalin $(0.1 \mathrm{~mL})$. The changes in paw edema were recorded for ten days and the results were analyzed.

\section{Statistical analysis}

Graph Pad Prism (Graph-Pad, San-Diego-CA, USA) was used for statistical analysis. Data are shown as mean \pm standard error of mean (SEM). ANOVA with post-hoc Tukey's test was applied to interpret data. $p<0.05$ was considered as significant.

\section{RESULTS}

\section{Docking results}

The ligand IO and ID were docked against different targets of pain and inflammation to obtain possible binding modes and binding affinities. The targets and their PDB IDs, binding affinities of ligand (IO and ID), standards (diclofenac sodium, zilueton, and morphine) and number of hydrogen bonds are shown in Table 1.

\section{Effect on acetic acid induced analgesia}

Acetic acid-induced pain method was used to determine the peripheral analgesic activity of both $\mathrm{IO}$ and ID and the results are shown in Figure 2. At 5 and $10 \mathrm{mg} / \mathrm{kg}, 10$ significantly decrease the writhes to $40 \pm 1.94$ and $21.2 \pm$ $2.10(p<0.001)$ respectively. ID at $5 \& 10 \mathrm{mg} / \mathrm{kg}$ also significantly decrease the writhes to $57.6 \pm$ 1.50 and $27.0 \pm 2.12(p<0.001)$ respectively.

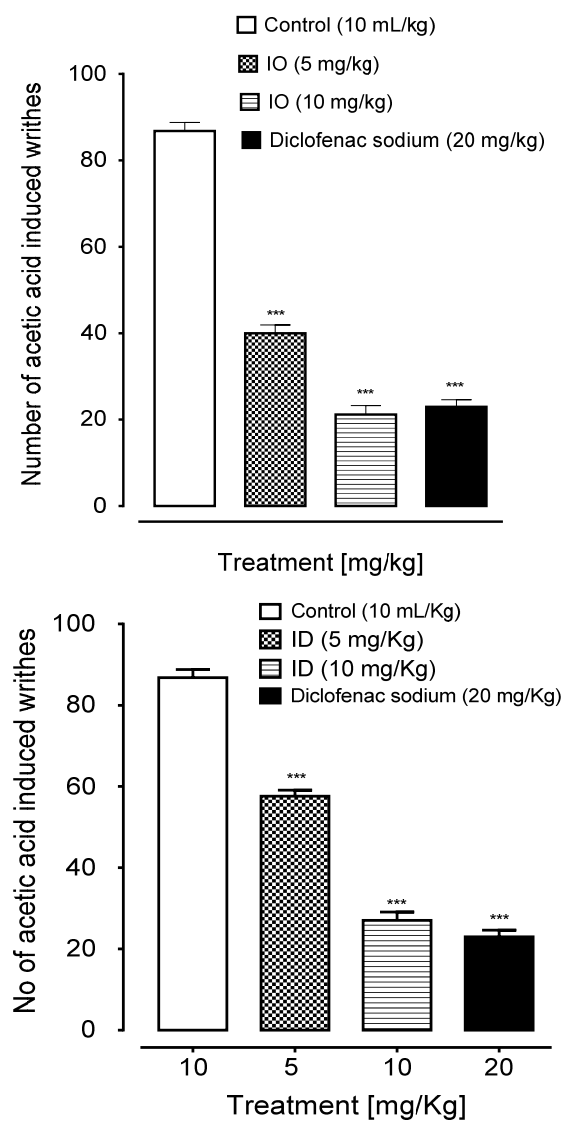

Figure 2: Bar chart showing inhibition of acetic acidinduced writhings by isosteviol 16-Oxime (IO), isosteviol 16-2, 4 dinitrophenyl hydrazine (ID) and diclofenac sodium in mice. Data shown as mean \pm SEM, $\mathrm{n}=5 ;{ }^{* * *} p<0.001$ vs. control, one-way ANOVA with post-hoc Tukey test

\section{Effect of treatment on latency time}

Hot plate method was used to determine the central analgesic effect of both IO and ID and the results are shown in Figure 2.10 at $10 \mathrm{mg} / \mathrm{kg}$ also significantly increase the latency period $(p<$ 0.001) after $60 \mathrm{~min}$. ID at dose $10 \mathrm{mg} / \mathrm{kg}$ increase the significantly increases latency period $(p<0.01)$.

\section{Effect on carrageenan-induced paw edema}

The anti-inflammatory effect of both $\mathrm{IO}$ and ID was determined by carrageenan-induced hind paw edema method and the results are shown in 
Figure 4. The mean paw volume recorded for IO at a dose of 5 and $10 \mathrm{mg} / \mathrm{kg}$ was significant at $(p$ $<0.01)$ and at $(p<0.001)$. The mean paw volume recorded for ID at a dose of 5 and 10 $\mathrm{mg} / \mathrm{kg}$ was significant at $(p<0.01)$ and at $(p<$ 0.001).

\section{Effect on formalin induced paw edema}

The test compounds IO and ID were screened for chronic inflammation through formalininduced paw edema and the results are shown in Figure 5. The paw volume displacement recorded for $\mathrm{IO}$ at dose $5 \mathrm{mg} / \mathrm{kg}$ and $10 \mathrm{mg} / \mathrm{kg}$ was significant at $(p<0.001)$. The paw volume displacement recorded for ID at dose $5 \mathrm{mg} / \mathrm{kg}$ and $10 \mathrm{mg} / \mathrm{kg}$ was significant at $(p<0.001)$.
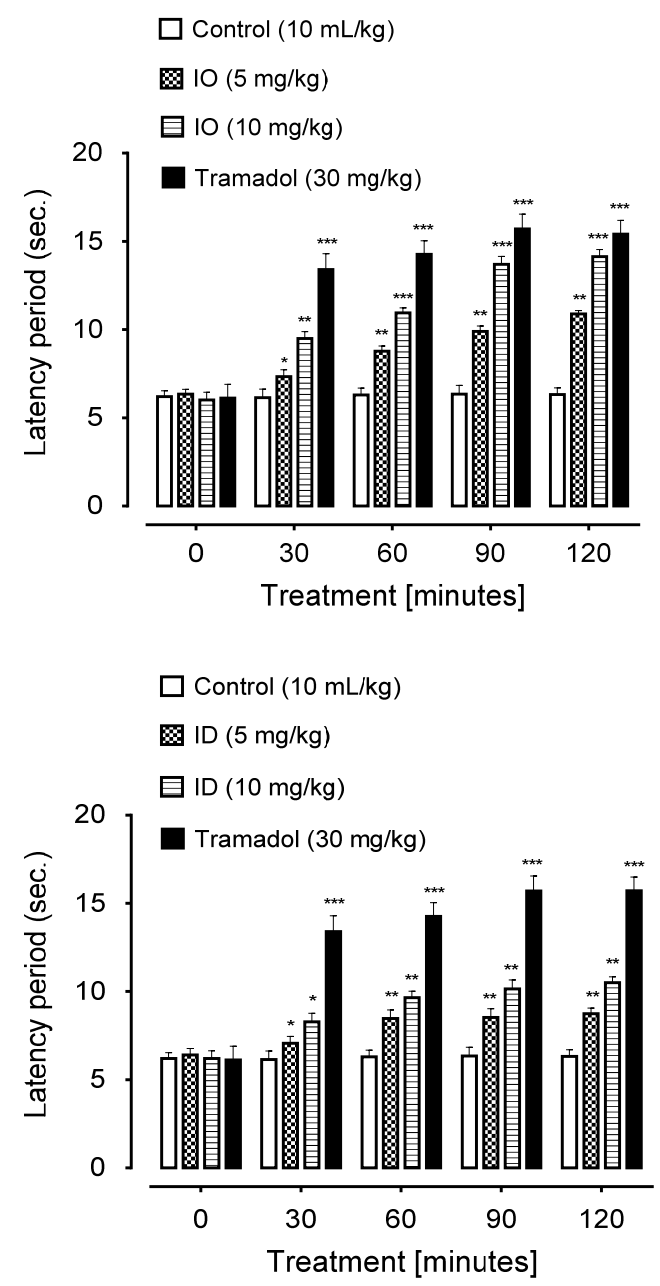

Figure 3: Bar chart showing the effect of isosteviol 16Oxime (IO), isosteviol 16-2, 4 dinitrophenyl hydrazine (ID) and tramadol on latency period of mice on hot plate. Data expressed as mean \pm SEM, $n=5 .{ }^{* *} p<0.01$ and ${ }^{* *} p<0.001$ vs. control, one-way ANOVA with posthoc Tukey test
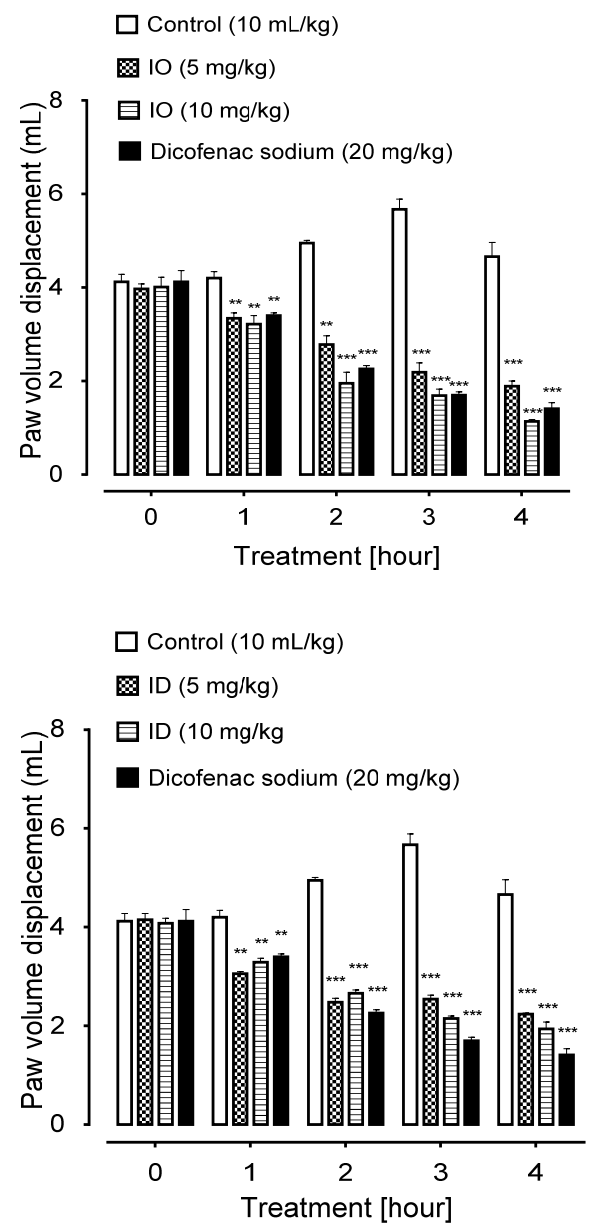

Figure 4: Bar chart showing inhibition of carrageenan induced paw edema by isosteviol 16-Oxime (IO), isosteviol 16-2, 4 dinitrophenyl hydrazine (ID) and diclofenac sodium in mice. Data expressed as mean \pm SEM, $n=5 .{ }^{* *} p<0.01,{ }^{* * *} p<0.001$ vs. control, one-way ANOVA with post-hoc Tukey test

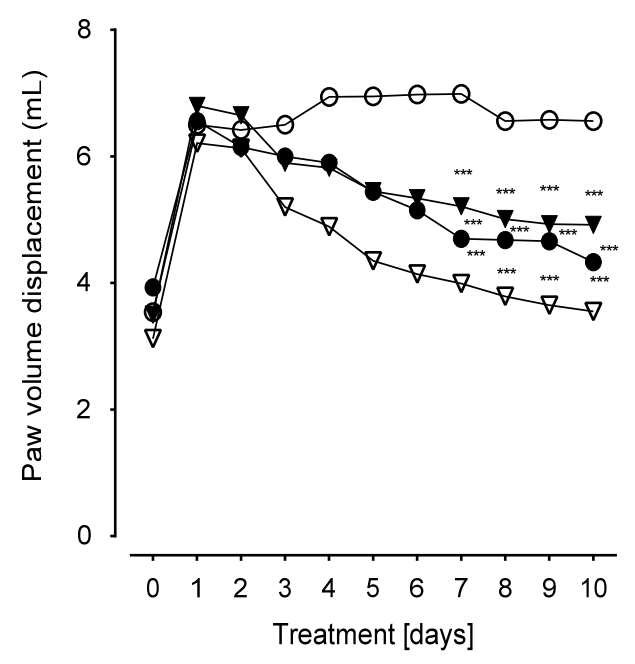

Trop J Pharm Res, August 2020; 19(8): 1681 


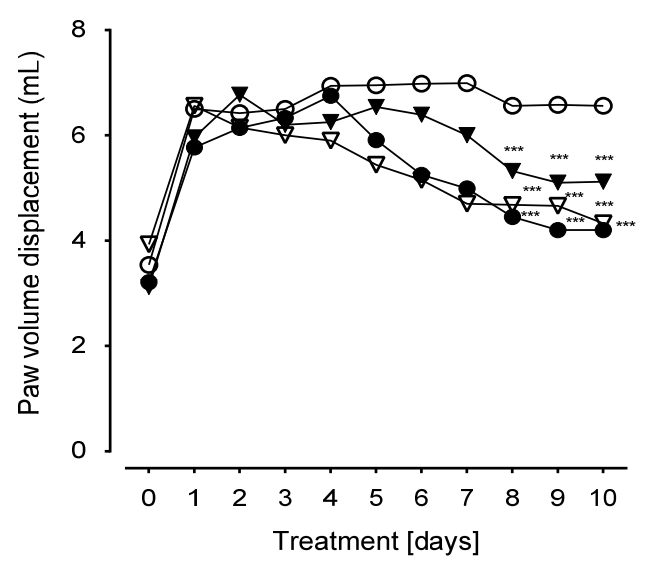

Figure 5. Bar chart showing inhibition of formalin induced paw edema by isosteviol 6-Oxime (IO), isosteviol 16-2, 4 dinitrophenyl hydrazine (ID) and diclofenac sodium in mice. $\circ$ control, $\nabla 5 \mathrm{mg} / \mathrm{kg}, \nabla$ $10 \mathrm{mg} / \mathrm{kg}$, • diclofenac sodium. Data expressed as mean \pm SEM, $n=5 .{ }^{* * *} p<0.001$ vs. control group, oneway ANOVA with post-hoc Tukey test

\section{DISCUSSION}

Docking is carried out with auto dock for the purpose to find the best interaction of the ligand (IO and ID) with target protein. This preliminary screening is helpful in order to confirm that weather the ligand molecule have the ability to become a drug candidate or not. These interactions are hydrogen bonds, hydrophobic interaction and wander wall forces [14]. The best and favorable interaction of a ligand with targets is correlated with good drug candidate of the future [15].

According to the Lipinski rule of five a good drug should of small size with molecular weight less than $500 \mathrm{Da}$ [16]. The ligand 10 gives best binding affinity against various targets because of its small size. Against COX-1 it gives two hydrogen bonds compare to ID which do not gives good binding with COX-1. The unfavorable bumps shown in red is the reason for the ID which make it less superior against COX-1. 10 is also found a good binder of COX-2 because it gives two hydrogen bonds with less bombs as compare to ID which gives one hydrogen and with 3 bumps. The superiority of $I O$ is continued against 5-LOX, 12-LOX and 15-LOX compare to ID in both in-silico and in-vivo models. Against PG synthase, comparatively 10 gives moderate binding better than ID.

Based on the bumps, the ID is again found not a good ligand of the LTC4 as compare to IO. The unfavorable bumps in ID makes are less affective against LTC4. IO was also noticed to possess moderate binding modes against all the opioids receptors. In short 10 is comparatively good ligand against targets for analgesia and inflammation. Pain and inflammation move side by side and starts in response to any type of stimulus/injury which provokes immune system. The stimuli may be mechanical or thermal origin [17]. Various inflammatory mediators are released to starts the process of inflammation. The mediators which are released in the early phase of the inflammation are histamine, bradykinin and 5-hydroxy tryptamine.

Some mediators like prostaglandins are released in the late phase of immune response [18]. The release of these mediators from different types of immune cells is termed as immunomodulation [19]. The immunomodulation is either immunostimulation or immunosuppression. The agents which play their role in causing immunomodulation are called as immunomodulator. These agents are gaining importance as they are involved in suppressing immune system and thus optimize response. These agents not only reduce inflammatory process but also lower pain perception associated with various pathological abnormalities [20]. According to literature, the stevioside and steviol glycoside are the key agents in attenuating inflammatory process.

The mechanism involved is the inhibition of various inflammatory cytokines (Nuclear factorKB (NF-KB), inhibitory kappa B (IKBa) protein, p38, extracellular signal-regulated kinase (ERK), and c-Jun N-terminal kinase (JNK) or proinflammatory mediators [21]. One another study also focuses the way of how stevioside lowers the immune response by preventing the over expression of certain inflammatory mediators, involved in pain and inflammation. It was also found that stevioside decreases the proinflammatory cytokines both in in-vivo and invitro models [22].

\section{CONCLUSION}

The results show that $I O$ is a promising candidate for the management of pain and inflammation. However, further studies, including pharmacokinetics and pharmacodynamics, are required to ascertain their suitability for clinical use.

\section{DECLARATIONS}

\section{Acknowledgement}

Authors are thankful to Riphah Academy of Research and Education, Islamic International Medical College Trust (IIMCT) and Riphah 
International University for financial support of the study.

\section{Conflict of interest}

No conflict of interest is associated with this work.

\section{Contribution of authors}

We declare that this work was done by the authors named in this article and all liabilities pertaining to claims relating to the content of this article will be borne by the authors. Sadaf Ahmad design and performed the experimental work. Arif Ullah khan and Muhammad Faheem work in writing of the manuscript. Asad Ullah and Shabir Ahmad synthesis and provide compounds. Muhammad Shahid Iqbal and Muhammad Akbar Hossain helps in improving the English language of the manuscript and financial support.

\section{Open Access}

This is an Open Access article that uses a funding model which does not charge readers or their institutions for access and distributed under the terms of the Creative Commons Attribution License (http://creativecommons.org/licenses/by/ 4.0) and the Budapest Open Access Initiative (http://www.budapestopenaccessinitiative.org/rea d), which permit unrestricted use, distribution, and reproduction in any medium, provided the original work is properly credited.

\section{REFERENCES}

1. Geuns JM. Stevioside. Phytochem 2003; 64(5): 913-921.

2. Melis MS, Sainati AR. Effect of calcium and verapamil on renal function of rats during treatment with stevioside. $J$ Ethnopharmacol 1991; 33(3): 257-262.

3. Geeraert B, Crombe F, Hulsmans M, Benhabiles N, Geuns JM, Holvoet $P$. Stevioside inhibits atherosclerosis by improving insulin signaling and antioxidant defense in obese insulin-resistant mice. Int J Obesity 2010; 34(3): 569-577.

4. Jeppesen $P B$, Gregersen $S$, Rolfsen SE, Jepsen $M$, Colombo M, Agger A, Xiao J, Kruhøffer M, Ørntoft $T$, Hermansen K. Antihyperglycemic and blood pressurereducing effects of stevioside in the diabetic GotoKakizaki rat. Metabolism 2003; 52(3): 372-378.

5. Yasukawa K, Kitanaka S, Seo S. Inhibitory effect of stevioside on tumor promotion by 12-Otetradecanoylphorbol-13-acetate in two-stage carcinogenesis in mouse skin. Biol Pharma Bull. 2002; 25(11): 1488-1490.

6. Boonkaewwan C, Toskulkao C, Vongsakul M. Antiinflammatory and immunomodulatory activities of stevioside and its metabolite steviol on THP-1 cells. J Agri Food Chem 2006; 54(3): 785-789.

7. Ullah A, Baratto LC, Paula RC, Silva LH, Soares MJ, Oliveira BH. Preparation of Derivatives of Betulinic Acid, Steviol and Isosteviol and Evaluation of Antitrypanosomal and Antimalarial Activities. $J$ of the Brazilian Chem Soc 2016; 27(7): 1245-1253.

8. National Research Council. Guide for the care and use of laboratory animals. National Academies Press; 2010.

9. Natarajan A, Sugumar S, Bitragunta $S$, Balasubramanyan N. Molecular docking studies of (4Z, 12Z)cyclopentadeca-4, 12-dienone from Grewia hirsuta with some targets related to type 2 diabetes. BMC Comp and Altern Med 2015; 15(1): 73.

10. Ahmed F, Selim MS, Das AK, Choudhuri MS. Antiinflammatory and antinociceptive activities of Lippia nodiflora Linn. Die Pharmazie-An Int $J$ of Pharm Sci 2004; 59(4): 329-330.

11. Zeghad N, Madi A, Helmi S, Belkhiri A. In vivo analgesic activity and safety assessment of Vitis vinifera $L$ and Punica granatum $L$ fruits extracts. Tropical Journal of Pharmaceutical Research 2016; 15(9): 1915-921.

12. Farghaly $A A$, Bekhit $A A$, Young Park J. Design and Synthesis of Some Oxadiazolyl, Thiadiazolyl, Thiazolidinyl, and Thiazolyl Derivatives of $1 \mathrm{H}$-Pyrazole as Anti-inflammatory Antimicrobial Agents. Archiv der Pharmazie: An Int J Pharm and Med Chem 2000; 333(2-3): 53-57.

13. Chen $H$, Pu J, Liu D, Yu W, Shao Y, Yang G, Xiang Z, He N. Anti-inflammatory and antinociceptive properties of flavonoids from the fruits of black mulberry (Morus nigra L.). Plos One 2016; 11(4).

14. Ayyappa B, Kanchi S, Singh P, Sabela MI, Dovey M, Bisetty K. Analytical evaluation of steviol glycosides by capillary electrophoresis supported with molecular docking studies. J of the Iranian Chem Soc 2015; 12(1): 127-136.

15. Cho AE, Guallar V, Berne BJ, Friesner R. Importance of accurate charges in molecular docking: quantum mechanical/molecular mechanical (QM/MM) approach. J Comp Chem. 2005; 26(9): 915-931.

16. Lipinski CA. Lead-and drug-like compounds: the rule-offive revolution. Drug Dis Today: Tech 2004; 1(4): 337241.

17. Fengyang L, Yunhe F, Bo L, Zhicheng L, Depeng L, Dejie L, Wen Z, Yongguo C, Naisheng Z, Xichen Z, Zhengtao $Y$. Stevioside suppressed inflammatory cytokine secretion by downregulation of NF-KB and MAPK signaling pathways in LPS-stimulated RAW264. 7 cells. Inflammation 2012; 35(5): 1669-1675.

18. Sehar I, Kaul A, Bani S, Pal HC, Saxena AK. Immune up regulatory response of a non-caloric natural sweetener, stevioside. Chemico-biol Int 2008; 173(2): 115-121.

19. Mossa JS, Rafatullah S, Galal AM, Al-Yahya MA. Pharmacological studies of Rhus retinorrhaea. Int $J$ Pharmacog 1995; 33(3): 242-246.

Trop J Pharm Res, August 2020; 19(8): 1683 
20. Bukhari IA, Gilani AH, Meo SA, Saeed A. Analgesic, antiinflammatory and anti-platelet activities of Buddleja crispa. BMC Complim Altern Med 2016; 16(1): 79.

21. Arya A, Kumar S, Kasana MS. Anti-inflammatory activity of in vitro regenerated calli and in vivo plant of Stevia rebaudiana (Bert.) Bertoni. Int J Sci Res Pub 2012; 2(8): 435-439.

22. Noosud J, Lailerd N, Kayan A, Boonkaewwan C. In vitro and in vivo assessment of inhibitory effect of stevioside on pro-inflammatory cytokines. Avicenna J Phytomed 2017; 7(2): 101. 